\title{
Forest biodiversity, relationships to structural and functional attributes, and stability in New England forests
}

\author{
Yude Pan ${ }^{1 *}$, Kevin McCullough ${ }^{2}$ and David Y. Hollinger ${ }^{1}$
}

\begin{abstract}
Background: Forest biodiversity is the foundation of many ecosystem services, and the effect of biodiversity on ecosystem functioning and processes (BEF) has been a central issue in biodiversity studies. Although many hypotheses have been developed to interpret global gradients of biodiversity, there has not been complete agreement on mechanisms controlling biodiversity patterns and distributions. Differences may be due to limited observation data and inconsistencies of spatial scales in analysis.
\end{abstract}

Methods: In this study, we take advantage of USDA Forest Service forest inventory and analysis (FIA) data for exploring regional forest biodiversity and BEF in New England forests. The FIA data provide detailed information of sampled plots and trees for the region, including 6000 FIA plots and more than 33,000 individual trees. Biodiversity models were used to analyze the data.

Results: Tree species diversity increases from the north to the south at a rate about 2-3 species per latitudinal degree. Tree species diversity is better predicted by tree height than forest age or biomass. Very different distribution patterns of two common maple species, sugar maple (Acer saccharum) and red maple (Acer rubrum), highlight the vulnerability of sugar maple and its potential replacement by red maple on New England landscapes. Red maple generally already outperforms sugar maple, and will likely and continuously benefit from a changing climate in New England.

Conclusions: We conclude that forest structure (height) and resources (biomass) are more likely foundational characteristics supporting biodiversity rather than biodiversity determining forest productivity and/or biomass. The potential replacement of red maple for sugar maple in the New England areas could affect biodiversity and stability of forest ecosystem functioning because sugar maple plays important ecological roles distinct from red maple that are beneficial to other tree species in northern hardwood forests. Such a change may not affect forest resilience in terms of forest productivity and biomass as these are similar in red maple and sugar maple, however, it would almost certainly alter forest structure across the landscape.

Keywords: Forest biodiversity, Biodiversity effect on function (BEF), New England, Forest inventory data, Species diversity, Latitudinal diversity gradient, Forest stability of ecosystem functioning, Forest resilience, Sugar maple, Red maple, Changing climate

\footnotetext{
* Correspondence: ypan@fs.fed.us

${ }^{1}$ USDA Forest Service, Durham, NH, USA

Full list of author information is available at the end of the article
} 


\section{Background}

Forests harbor the majority of species on Earth and provide valuable ecosystem goods and services to humanity (Pan et al. 2013). Forest biodiversity is the foundation of many ecosystem services, and individual species traits play an important role in determining ecosystem functioning and processes (Naeem et al. 2009). Forest structural complexity, defined by attributes such as physiognomies, growth forms, and ages, appears to have a close link to forest biodiversity. As forests change along the latitudinal gradient from boreal regions towards the equator, their structural complexity and biodiversity also increase (Pan et al. 2013). Increasingly complex forest structures enable diversified microclimates, niches, and habitats for maintaining biodiversity.

Broad-scale spatial patterns of biodiversity across the earth have interested ecologists who have long explored the theoretical and practical causes and consequences of these patterns (Gaston 2000). These studies are inevitably important to understanding biodiversity on the earth, for guiding conservation strategies, and for investigating relationships between ecosystem functions, structure, and species diversity, although there are still many disagreements and different theories about foundational mechanisms controlling biodiversity patterns and distributions (He and Legendre 2002; Rahbek 2005). Some differences may be attributed to limitations in observation data, specifically varying sampling areas and different spatial scales in analysis, as the effects of area and scales on species diversity and distribution patterns have been very well recognized (Whittaker 1970; Gotelli and Colwell 2001; Lyons and Willig 2002; Clark and McLachlan 2003; Ricklefs and $\mathrm{He}$ 2016). It remains challenging, however, to collect sufficient data for testing various biodiversity hypotheses and mechanisms of biodiversity-functioning interactions at different scales (Loreau et al. 2001; Griffin et al. 2009; Brose and Hillebrand 2016). This may be particularly important at regional and landscape scales, as these scales are most relevant to land management, conservation activities, and mitigation strategies under a changing climate which is likely to affect species distribution and migrations (Iverson et al. 2008; Díaz et al. 2009).

Taking advantage of high quality forest inventory data collected by the USDA Forest Service, this study identifies tree species diversity patterns across New England landscapes, investigates relationships between forest biodiversity and forest structural or functional attributes, and explores potential impacts of climate change on tree species distributions. The study is critical for understanding the future of forests in the New England states, and for evaluating their functional stability and resilience to changing climate and changing disturbance regimes, both of which would alter forest structures, function, and tree species composition. It provides valuable information of local and regional patterns of tree species diversity, approaches for estimating local tree species, and interpretations of relationships between biodiversity and forest attributes that benefit forest management across New England landscapes.

\section{Methods}

\section{Study area and data}

New England refers to a region of six states in the northeastern corner of the Unite States. From north to south it includes Maine, New Hampshire, Vermont, Massachusetts, Rhode Island and Connecticut. Topographically, the western regions of New England are mountainous, running from north to south as part of Appalachian Mountains range, and the eastern regions are coastal areas facing the Atlantic Ocean (Fig. 1a). These geographical features affect climate patterns within New England, which is generally colder and drier in the northwest, warmer and wetter in the southeast (Fig. 1b and c).

The US Forest Service forest inventory and analysis data (FIA) at tree/plot levels were derived from the national database for New England states between latitudes $41^{\circ} 05^{\prime} \mathrm{N}$ and $47^{\circ} 26^{\prime} \mathrm{N}$ (Table 1 ). We used the most recently collected data (2011-2016) from FIA Phase 2 and Phase 3 plots (https://www.fia.fs.fed.us/li brary/database-documentation/index.php). The Forest Service FIA program has established more than 300,000 permanently plots nationwide and measured millions of trees in the plots with detailed records. Each plot contains 4 subplots and represents a combined sampling area of $\sim 672.5 \mathrm{~m}^{2}$ spread out across $\sim 0.4$ ha (or 1 acre) (Anonymous 2017). For the New England states, the data used for this study come from 6096 inventory plots and 334,057 individual trees (Table 1). The variables we selected and processed for this study include plot data of forest age, height and living biomass, and individual tree data of each species in each plot, including $\mathrm{DBH}$ and basal area. These plot and individual tree data provide necessary information for examining forest structure, function, and tree species diversity.

\section{Methodologies}

We divided the landscape of each state into latitudinal bands of $\sim 20$ ', which is roughly equal to $37 \mathrm{~km}$ in distance. The inventory plots in each latitudinal band were combined to count the number of tree species, for estimating species richness in each latitudinal band $(S$, Eq. 1), estimating area-based tree species richness or diversity (SppD, Eq. 2), and calculating biodiversity indices including Simpson's diversity index $(D)$ and Simpson's index of diversity (SID) (Eqs. 3 and 4). Biomass, forest age, and tree height plot data were averaged to represent mean values of the latitudinal band. As SID was used to 


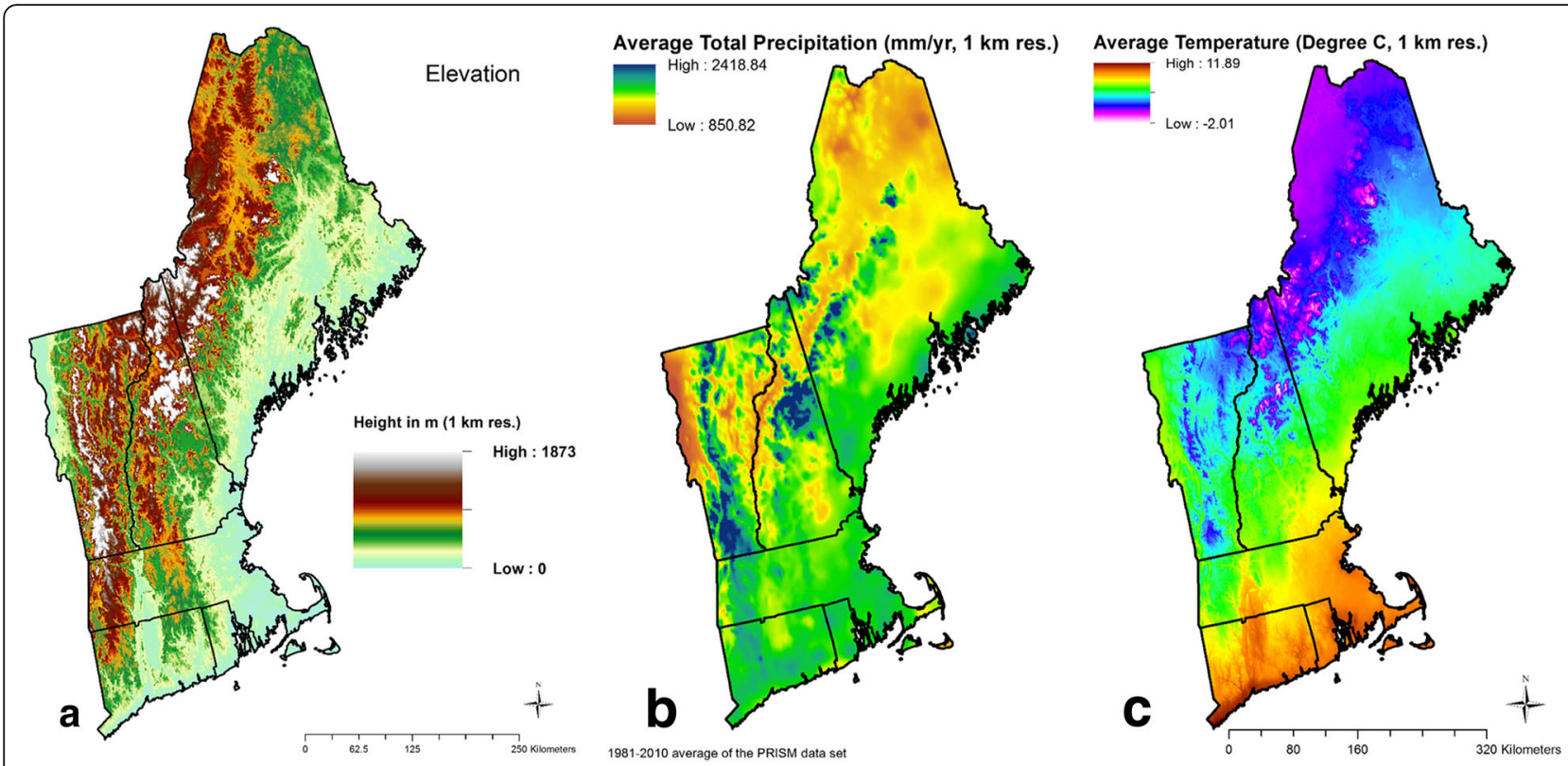

Fig. 1 New England topography and climate: a elevation; b 30-years' mean of annual precipitation (1981-2010); and c 30-years mean of annual average temperature

represent $\alpha$ diversity of latitudinal bands, we use SID to further calculate regional $\gamma$ diversity for each state using all tree species data of that state, and $\beta$ diversity representing a ratio of regional versus local diversity and reflecting a degree of species turnover (Eqs. 5, 6 and 7).

To identify the likely response of a single species to regional environmental changes, the first step is to determine its distribution and current status. This addresses concerns about forest biodiversity stability and functional resilience on New England landscapes in the future. Two of the most common maple species in New England were selected for the purpose, sugar maple (Acer saccharum) and red maple (Acer rubrum). The species abundance (SppA) and importance value (IV) of the two species were calculated for the latitudinal bands (Eqs. 8 and 9).

Table 1 Forest inventory data of New England States along eastern coast gradients

\begin{tabular}{lllll}
\hline State & Plots & $\begin{array}{l}\text { Measured } \\
\text { trees }\end{array}$ & Species & Latitude \\
\hline Maine & 3150 & 196,536 & 56 & $43^{\circ} 06^{\prime} 24^{\prime \prime}-47^{\circ} 26^{\prime} 14^{\prime \prime} \mathrm{N}$ \\
New Hampshire & 1047 & 58,813 & 65 & $42^{\circ} 42^{\prime} 13^{\prime \prime}-45^{\circ} 16^{\prime} 17^{\prime \prime} \mathrm{N}$ \\
Vermont & 920 & 43,935 & 62 & $42^{\circ} 44^{\prime} 02^{\prime \prime}-45^{\circ} 00^{\prime} 46^{\prime \prime} \mathrm{N}$ \\
Massachusetts & 534 & 20,329 & 74 & $41^{\circ} 14^{\prime} 58^{\prime \prime}-42^{\circ} 40^{\prime} 11^{\prime \prime} \mathrm{N}$ \\
Rhode Island & 124 & 4020 & 48 & $41^{\circ} 21^{\prime} 07^{\prime \prime}-42^{\circ} 00^{\prime} 44^{\prime \prime} \mathrm{N}$ \\
Connecticut & 317 & 10,340 & 62 & $41^{\circ} 05^{\prime} 22^{\prime \prime}-42^{\circ} 02^{\prime} 25^{\prime \prime} \mathrm{N}$ \\
Summary & 6096 & 334,057 & 93 & $41^{\circ} 05^{\prime} 22^{\prime \prime}-47^{\circ} 26^{\prime} 14^{\prime \prime} \mathrm{N}$ \\
\hline
\end{tabular}

We used the following equations for calculations:

Species richness of a latitudinal band $\left(\operatorname{SppR}_{\mathrm{L}}\right)=S$

Here, $S$ is the number of tree species found in all FIA inventory plots in a latitudinal band.

$$
\text { Species diversity }(\mathrm{SppD})=\frac{S}{\log A}
$$

Here, we use Whittaker's definition of species diversity (SppD) to express species richness as a logarithmic function of sampling area (Whittaker 1970). Where, $S$ is the number of tree species in all inventory plots of a latitudinal band and $A$ is the total sampled area. Although the real sampled area of 4 subplots in each inventory plot is $\sim 672.5 \mathrm{~m}^{2}$, each inventory plot spreads out across and represents $\sim 0.4$ ha sampling area because of the plot design. As inventory plots are randomly distributed in each latitudinal band, they should represent sampled species diversity much better than from a large single site. The total sampling area $(A)$ was then calculated for the latitudinal band using all FIA plots in it.

$$
\text { Simpson's index }(D)=\sum\left(\frac{n}{N}\right)^{2}
$$

Here, $n$ is the number of trees of a particular species from sampled plots of a latitudinal band, and $N$ is the total number of trees of all species from sampled plots of the latitudinal band. 


$$
\text { Simpson's index of diversity }(\mathrm{SID})=1-D
$$

Here, SID is a measure of both biodiversity and evenness, where a greater value means greater biodiversity and evenness.

$\alpha$ diversity $=\operatorname{SID}($ summed over a latitudinal band in a state)

$$
\gamma \text { diversity }=1-\sum\left(\frac{n}{N}\right)^{2}
$$

Here $n$ is the number of trees of a particular species from all sampled plots in a state, and $N$ is the total number of trees of all species from all sampled plots of the state.

$$
\beta \text { diversity }=\frac{\gamma}{\alpha}
$$

Here, $\beta$ diversity is a ratio of regional biodiversity vs. local biodiversity, by using the index SID for the calculations (not species numbers as some studies use), it quantifies the degree of differentiation in both species diversity and evenness among latitudinal bands.

We calculate species abundance and importance value for two species of maple.

$$
\text { Species abundance }(\operatorname{SppA})=\frac{n}{N}
$$

Here, $n$ is the tree number of sampled sugar maple or red maple respectively, $N$ is the tree number of sampled all tree species.

$$
\begin{aligned}
\text { Importance Value }(\mathrm{IV}) & =(\mathrm{RF}+\mathrm{RD}+\mathrm{RB}) \times \% \\
& =\left(\frac{f}{F}+\frac{d}{D}+\frac{b}{B}\right) \times \%
\end{aligned}
$$

Here, RF is relative frequency as $F$ is the number of sampled plots and $f$ is the plot number with the occurrence of a maple species; RD is relative density as $D$ is the number of trees of all species per area and $d$ is the number of trees of a maple species per area; and RB is relative basal area as $B$ is total basal area of all species and $b$ is the total basal area of a maple species.

\section{Results}

\section{Forest tree diversity trends and patterns}

Along the latitudinal gradient, Species Diversity decreases significantly $(P<<0.01)$ from south to north (i.e. from lower latitudes towards higher latitudes, see Table 2) although there is some evidence of higher than expected diversity in northern Vermont and southern Massachusetts (Fig. 3a). The numbers of species (Species Richness) in latitudinal bands are affected by sampling areas (or numbers of plots) in latitudinal bands. Because of different shapes and areas of different New England states, the sizes of latitudinal bands are different among them. Land-use (percentage of land in forest) also varies

\begin{tabular}{|c|c|c|c|c|}
\hline Relationships & Linear/non-linear & Equations & $R^{2}$ & $p$ \\
\hline Latitude-tree height & Non-linear & $H=16.80-4.83 / \operatorname{EXP}(0.35 \times($ Lat-45.96)^2) & 0.79 & $<0.0001$ \\
\hline Latitude-total biomass & Non-linear & $\mathrm{BM}=109.23+91.28 / \mathrm{EXP}\left(0.31 \times(\text { Lat-42.83 })^{\wedge} 2\right)$ & 0.72 & $<0.0001$ \\
\hline Latitude-species richness & Linear & $S=178.85-3.18 \times$ Lat & 0.35 & 0.0002 \\
\hline Latitude-species diversity & Linear & SppD $=139.15-2.66 \times$ Lat & 0.66 & $<0.0001$ \\
\hline Latitude-Simpson's index of diversity & NA & NA & NA & NA \\
\hline Age-tree height & Linear & $H=1.33+0.20 \times$ Age & 0.65 & $<0.0001$ \\
\hline Age-total biomass & Linear & $\mathrm{BM}=-136.65+0.37 \times$ Age & 0.81 & $<0.0001$ \\
\hline Age-species richness & Linear & $S=-19.60+0.87 \times$ Age & 0.54 & $<0.0001$ \\
\hline Age-species diversity & Linear & $\mathrm{SppD}=-14.60+0.55 \times$ Age & 0.59 & $<0.0001$ \\
\hline Age-Simpson's index of diversity & Non-linear & $\mathrm{SID}=0.89+609.65 \times \operatorname{EXP}(1-0.16 \times \mathrm{Age})$ & 0.56 & $<0.0001$ \\
\hline Height-total live biomass & Linear & $\mathrm{BM}=-90.60+16.52 \times H$ & 0.74 & $<0.0001$ \\
\hline Height-species richness & Linear & $S=-4.82+2.90 \times H$ & 0.39 & $<0.0001$ \\
\hline Height-species diversity & Linear & $\mathrm{SppD}=-12.29+2.30 \times H$ & 0.66 & $<0.0001$ \\
\hline Height-Simpson's index of diversity & Linear & $S I D=0.75+0.0084 \times H$ & 0.30 & 0.0006 \\
\hline Species richness-total biomass & Non-linear & $\mathrm{BM}=237.76+330.66 \times \operatorname{EXP}(1-0.038 \times S)$ & 0.45 & $<0.0001$ \\
\hline Species diversity-total biomass & Non-linear & $\mathrm{BM}=203.08+780.00 \times \operatorname{EXP}(1-0.14 \times \mathrm{SppD}))$ & 0.61 & $<0.0001$ \\
\hline Simpson's index of diversity-total biomass & Linear & $\mathrm{BM}=-510.43+766.18 \times \mathrm{SID}$ & 0.38 & $<0.0001$ \\
\hline
\end{tabular}
but usually there are more sampling plots and sampled areas in latitudinal bands with greater area (Fig. 2). There is a linear relationship between Species Diversity and Species Richness in latitudinal bands (Fig. 3b).

Table 2 Relationships among variables of latitude, forest structural and functional attributes and biodiversity indices

Note: $p$ values from the F-test show that all regression models are statistically significant, given a significance level of 0.01 . The values with bold fonts show the highest $\mathrm{R}^{2}$ coefficient of determination among the fitted regression curves in a group of the same independent variable 


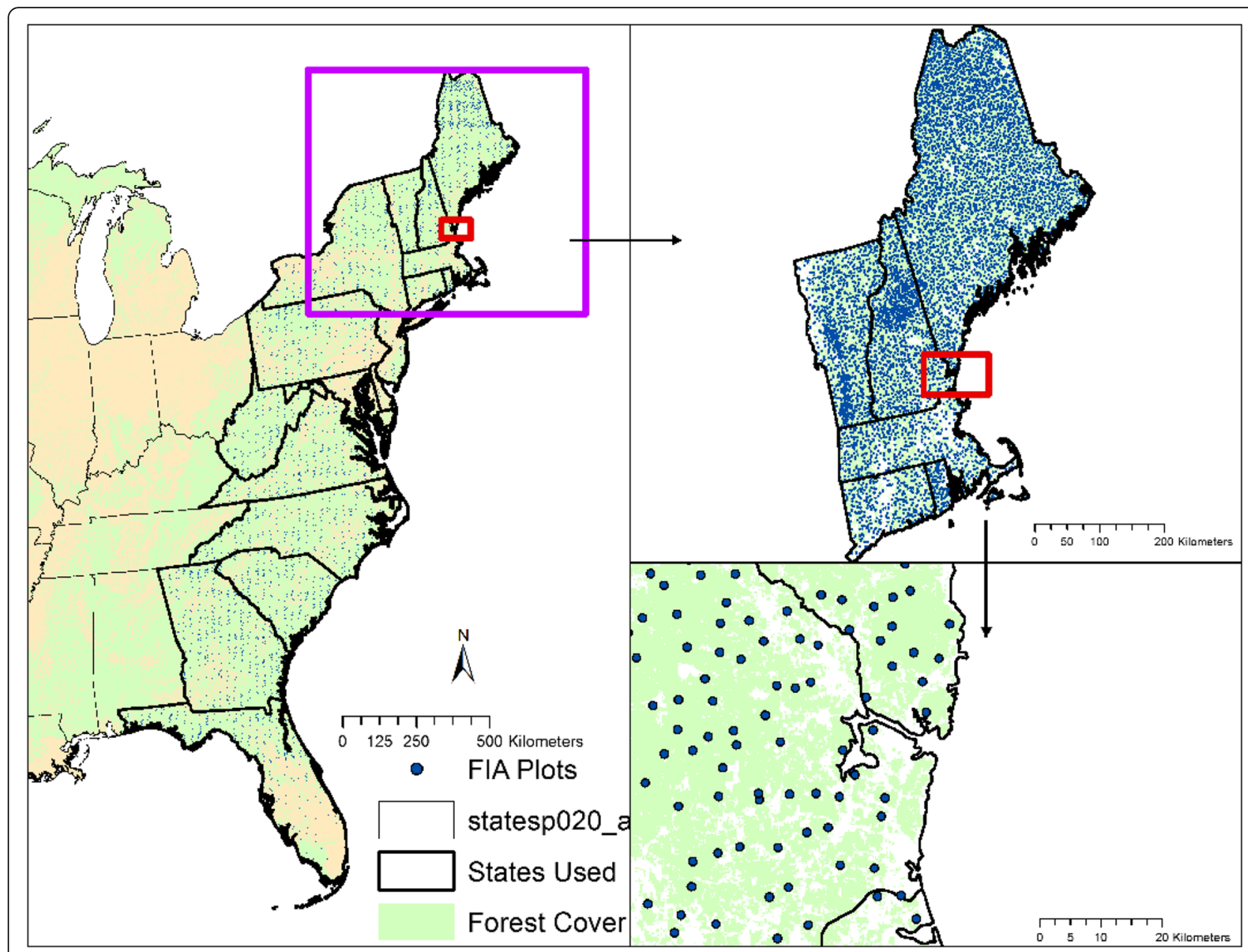

Fig. 2 The sampling plots of the USDA Forest Service Forest Inventory Analysis Program (FIA) in New England states

The species diversity index, Simpson's Index of Diversity (SID), was used to calculate $\alpha$ diversity of the latitudinal bands (Fig. 4a). It does not show any obvious trends along the latitudinal gradient, instead exhibiting a wavy pattern across the latitudinal gradient (Fig. 4a). The $\beta$ diversity also has a wavy pattern (Fig. 4b), indicating the degree of differentiation in biodiversity (SID) between regional (states) and local (bands) scales. A higher $\beta$ value signifies that SID in a latitudinal band is less than and deviates from the regional value, while a $\beta$ value lower
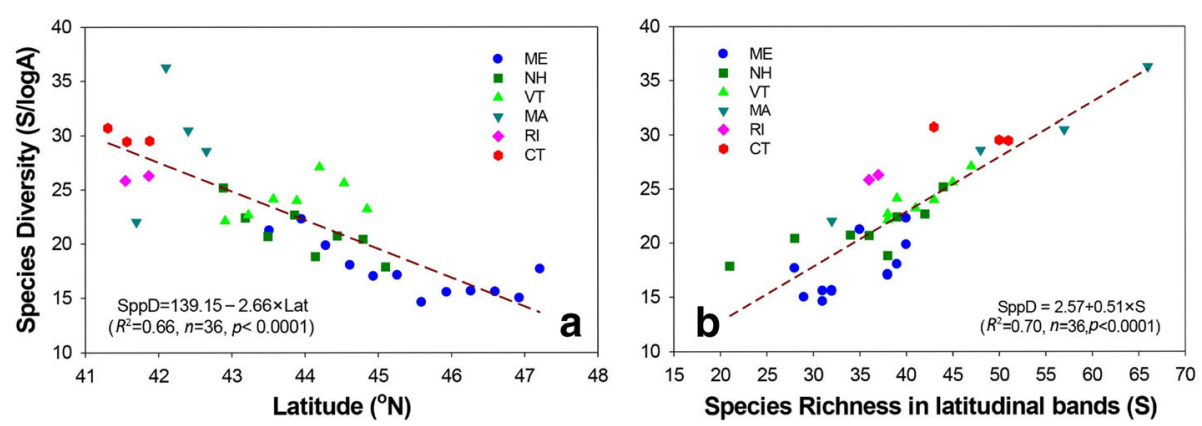

Fig. 3 a Species Diversity (SppD) along the latitudinal gradient of New England; $\mathbf{b}$ relationship between Species Richness in the latitudinal bands (S) and Species Diversity. Lines show regressions for data fitting 

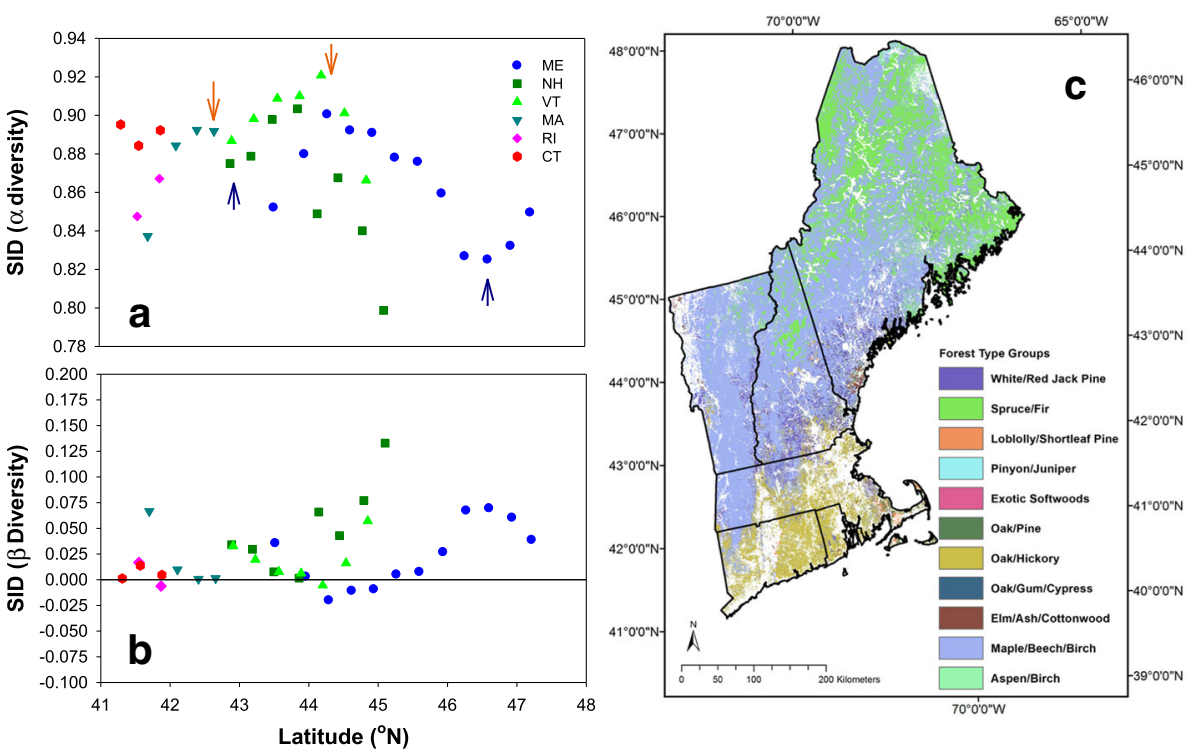

Fig. 4 Simpson's index of diversity along the latitudinal gradient. a a diversity (in each latitudinal band) representing local diversity; b $\beta$ diversity a ratio of regional diversity ( $\gamma$ diversity for each state) and local diversity (a diversity); and $\mathbf{c}$ the distribution of forest types that correspond to biodiversity indices. Arrows in (a) showing the transition zones of forest types

than 1 implies that species diversity or evenness in the latitudinal band is higher than the region.

\section{Relationships between biodiversity and forest structural or functional attributes}

We explore all possible relationships among all available variables of latitude, forest structural and functional attributes, and biodiversity indices (Table 2). In terms of the relationships between different species diversity indices $(S, S p p D, S I D)$ and forest structural/functional attributes (age, height, biomass), tree height has the best relationship with species diversity $\left(R^{2}=0.66\right.$, Table 2 and Fig. 5b). Forest biomass is also related to species diversity but with a lower $R^{2}$ coefficient $(0.61)$ than tree
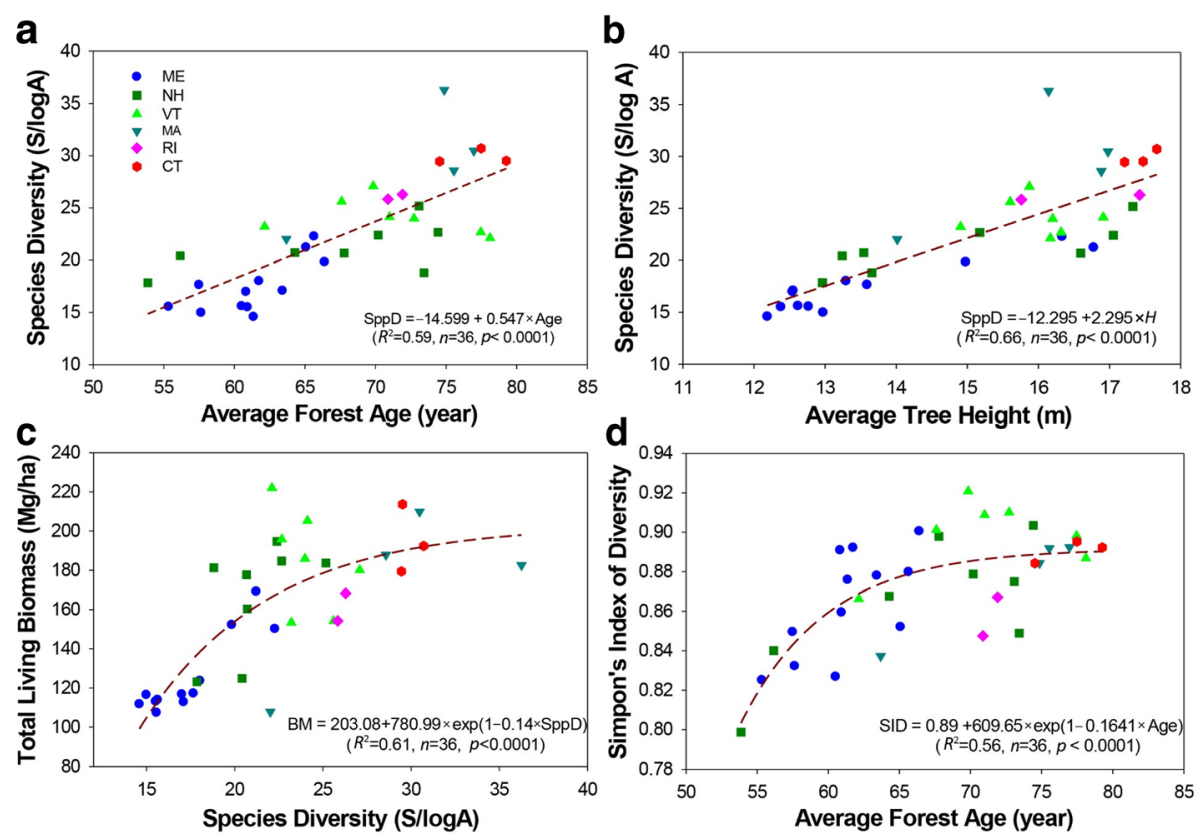

Fig. 5 Relationships between biodiversity indices and forest structural or functional attributes. a Age-SppD; b Height-SppD; c SppD-Living biomass; and d Age-SID 
height (Fig. 5c). Only forest age has a fair relationship with biodiversity index SID ( $R^{2}$ of 0.56 , Fig. $5 \mathrm{~d}$ ), as tree height and biomass are weakly related to SID ( 0.30 and 0.38 respectively, Table 2). Forest age is also reasonably well-related to species diversity $\left(R^{2}\right.$ of 0.59$)$ (Fig. 5a), species richness (0.54), and SID (0.56).

\section{Distributions of maple species}

The results of Species Abundance and Importance Values for sugar maple and red maple are shown in Fig. 6. The two maple species reveal very different features across New England landscapes. Both Species Abundance and Importance Value of red maple are higher than those for sugar maple across most latitudinal bands except in Vermont and northern New Hampshire (Fig. 6).

\section{Discussion}

Across the geographical domain of New England states, this work represents an initial study for examining relationships and interactions among forest species diversity, functional processes, and structure complexity in temperate forests of the Conterminous US. Although relatively more studied than other forest biomes in the world, temperate forests are unique because of their close connections to human habitation and long history of anthropogenic interference. Their ecological importance and key roles in transition zones between boreal and tropical ecosystems and in global forest systems hold many unanswered questions. Compared to tropical and boreal forests, the former, under a relatively uniformed climate, have complex forest structures and niches often producing many endemic species, while the later, suffering harsh climates, tend towards relatively simple forest structures with limited tree species. Temperate forests, with wide ranges of biogeographical and climate variations, and with sufficient complexity in forest structure and a variety of tree species, are perhaps ideal for exploring interactions and relationships among all elements of forest ecosystems. In the following sections, we discuss the results of data analyses and observations from the areas centered by typical northern hardwood forests and edged with transition zones respectively towards southern hardwood forests and northern coniferous forests.

\section{Latitudinal trends and patterns of forest tree diversity}

The latitudinal diversity gradient (LDG) is one of the most widely recognized patterns in ecology (Gaston 2000). Many hypotheses have been generated to account for these findings including biogeographical history, evolutionary history, and climate. However, these hypotheses and concerns are mostly based on observations at a global or large scale, looking at gradients across tropical, temperate and boreal systems. Our study is based on a small regional scale that covers northern temperate forests across New England landscapes over about $710 \mathrm{~km}$ in latitudinal distance. Even so, our results display a clear latitudinal gradient in tree species diversity, showing an increase rate of approximately $2-3$ species from north to south per latitudinal degree (Fig. 3a). Given such a relatively small geographical domain, and relatively uniformed effects of glaciers from the last Ice Age and human land-use histories which altogether have formed New England
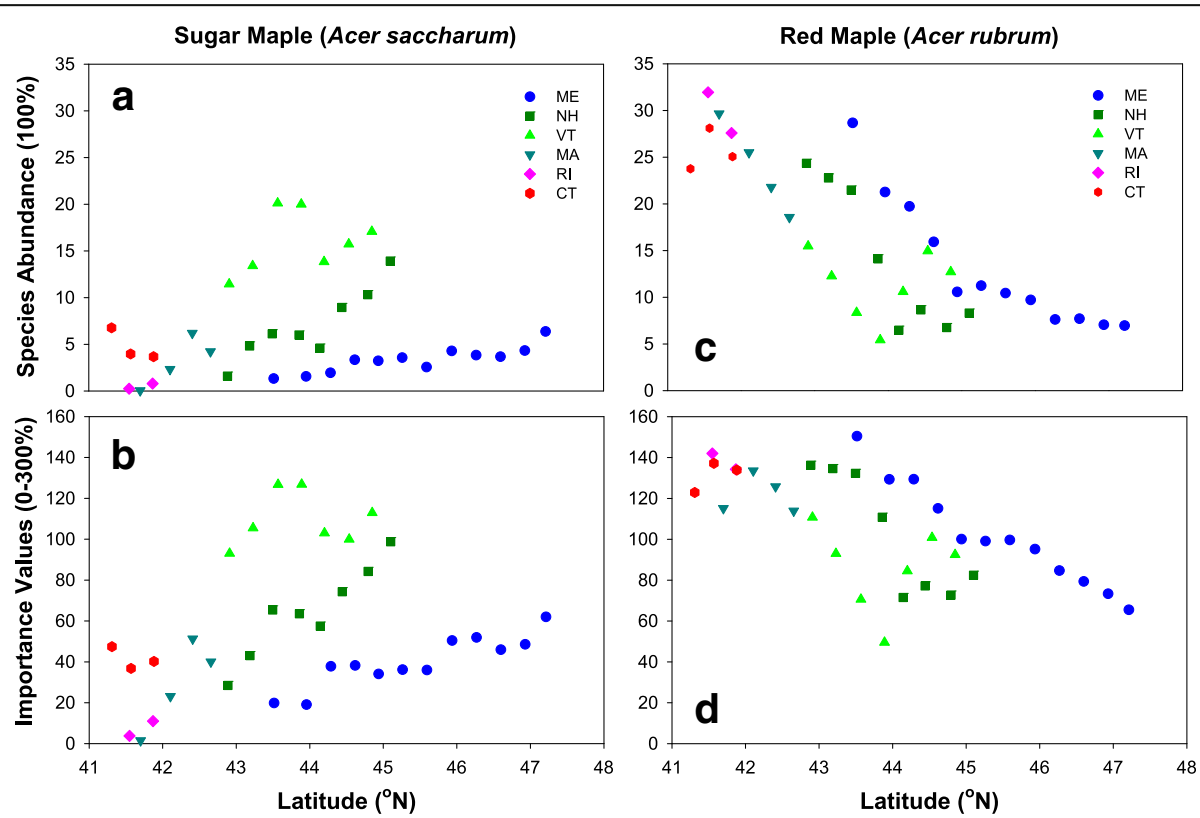

Fig. $\mathbf{6}$ Species abundance (a) and importance value (b) of sugar maple; species abundance (c) and importance value of red maple (d) 
landscapes, the LDG on the New England gradient is likely to reflect conserved environmental adaptations of species to climate factors (Kerkhoff et al. 2014).

For representing local species richness, there is another hotly debated issue regarding the effect of spatial scales on species richness, in another words, the effect of the size of the sampling units (Rahbek 2005). For the sake of comparison, a standard size of sampling area is supposed to be used or the sampled species numbers need to be rationalized using a species-area relationship (Whittaker 1970). Because latitudinal bands we created for each state are different in sizes, as well as the numbers of sampling plots and sampled areas, we used a logarithmic function of total sampling area (of all FIA plots) in a latitudinal band to normalize the number of species recorded and calculate species diversity, necessary for comparison.

However, it has been always a problem in biodiversity studies about what is a reliable description of local species richness because of the scale effect (here it is more about a range and areal extent in a study). A linear relationship between the species richness in a latitudinal band and species diversity (i.e. species richness normalized by sampled area) shows species diversity is positively related to richness in latitudinal bands (Fig. 3b), which is consistent with a study at much greater scales that suggests a similar linear relationship existing between local and regional species richness regardless of taxa and regions (Lyons and Willig 2002). The species diversity in our study represents $45-85 \%$ of species richness in latitudinal bands. Further, a covariance analysis for the linear regression in Fig. 3b shows about $30 \%$ of the variation is likely attributed to the effect of various sizes of latitudinal bands, which is consistent with the results of linear regressions with and without considering the scale effect on species numbers in latitudinal bands (Table 2). Nevertheless, there remains about $32 \%$ of the variance in species diversity that cannot be interpreted, likely attributed to edaphic patterns such as calcareous soils in Vermont (Siccama 1974), topographical features prominent in longitudinal directions, and the impacts on climates (Fig. 1), as well as possible biotic interactions among tree species.

Simpson's index of diversity (SID) is a measure of both species diversity and evenness, and is not particularly affected by spatial scales (Eq. 3 and Eq. 4). We used SID to calculate $\alpha$ diversity (local diversity) for each latitudinal band (Fig. 4a) and $\gamma$ diversity (regional diversity) for each state to derive $\beta$ diversity of each latitudinal band (Fig. $4 \mathrm{~b}$ ). SID along the latitudes does not show any trends, but rather wavy patterns, with high values around $42^{\circ} 30^{\prime}$ and $44^{\circ}$, and low points around $43^{\circ}$ and $46^{\circ} 30^{\prime}$ in latitude (Fig. 4a). These higher points just correspond to centers of forest types and lower points to the transition zones of a forest type shifting from one to another (Fig. 4c).

The $\beta$ diversity, a measure of a differentiation rate of regional SID (states) comparing to local SID (bands), also shows wavy patterns that are consistent, to some degree, among bands of different states (Fig. 4b). A latitudinal range of $\beta$ values that form a concave shape between latitudes of $43^{\circ}-46^{\circ} \mathrm{N}$ corresponds precisely to the range of northern hardwood forests dominated by maple-beech-birch species (Fig. 4c). Higher $\beta$ values occur around latitudinal $43^{\circ} \mathrm{N}$ and $46^{\circ} 30^{\prime} \mathrm{N}$, confirming $\alpha$ diversity for transition zones with greater changes in SID from northern hardwood forests towards southern oak-hickory forests and towards northern boreal sprucefir forests, respectively. Some higher $\beta$ diversity values occur in northern New Hampshire and Vermont (Fig. 4b), which are likely due to their locations among the mountainous ranges and valleys (Fig. 1a) that increase unevenness in species distribution.

Instead of latitudinally determined diversity (LDG), some theories suggest that species diversity should increase towards the center of a geographic domain, which is described as the mid-domain effect (Colwell and Lees 2000). Our results show that species diversity across the New England latitudinal gradient is more dominated by a monotonic decreasing pattern from the south to north (Fig. 3a). There are, however, some hump-shaped areas along the gradient indicating higher species diversity in Vermont and Massachusetts (Fig. 3a). These hotspots correspond to certain forest type domains happening to share physiographical boundaries in range distributions. For instance, around a Vermont latitudinal band at $44^{\circ}$ $\mathrm{N}$, maple-beech-birch forests and white-red-jack pine forests are both at their central domains of distribution ranges (Fig. 4c). However, such a mid-domain diversity peak occurs on a scale smaller than the total New England latitudinal range. Thus, the spatial scale represented in a study appears to be important for interpreting biodiversity patterns.

\section{Relationships of biodiversity to forest structural and functional attributes}

The relationship between biodiversity and ecosystem function (BEF), has interested many ecologists. For instance, studies exploring the relationship between species diversity and forest productivity or biomass show positive relationships and effects (e.g. Cardinale et al. 2007; Liang et al. 2016), while other studies suggest no clear relationships between species diversity and carbon storage (Steege et al. 2013; Sullivan et al. 2017). Again, this may reflect the impact of scale on the relationships and patterns (Waide et al. 1999; Gaston 2000; Rahbek 2005).

Across the New England landscape, our data show that forest age, tree height, and biomass all have significant 
relationships with species diversity (Table 2 and Fig. 5). Among these forest variables, tree height $(H)$ has the best relationship with species diversity, explaining similar variation in species diversity as latitude (Table 2). The relationship ought to suggest tree height $(H)$ more likely to be a cause than an effect of species diversity. Forest age is an indicator of forest stand development, and closely related to forest tree height and particularly, biomass (Table 2). The relationships between species diversity and three forest attributes (age, height, and biomass) are obviously not independent to each other, all are related to the effect of time on the process of forest development, and species occurrence and establishment in situ. However, tree height as the best variable for interpreting species diversity may suggest that forest structural complexity plays a more foundational role for species diversity, as tree height is a direct indicator of structural complexity (Franklin et al. 2002), which echoes forest development and succession, and also the limits of environmental conditions and topography. Moreover, tree height has a stronger correlation with biomass than with species diversity ( $R^{2}$ of 0.74 vs. 0.66$)$ and as an important variable determining biomass, which suggests that biomass would more likely be an underpinning to support species diversity than be regulated by it. That said, the relationship between biodiversity and forest biomass (Fig. 5a) may not be cause and effect, which is more likely due to the impacts of forest age and tree height on biomass (Table 2).

Simpson's index of diversity (SID, Eq. 3), not Simpson's diversity index $(D)$ (Eq. 2), is used to make the index represent biodiversity consistently with its values, i.e. greater values mean greater biodiversity and species evenness, rather the opposite as $D$ does. Our results show that forest age accounts for a majority of the variance in SID, and more than either height or biomass (Table 2). Forest age accounts for about $56 \%$ of variation in SID (Fig. 5d), suggesting an older forest gains higher species diversity and evenness. As biodiversity is linked to the stability of ecosystem processes (Griffin et al. 2009), we might conclude that older forests with higher species biodiversity could be more stable in terms of ecosystem functioning.

\section{Distributions of maple species and implications}

There are many concerns about how forests would respond to altering environmental conditions in the future. In New England, warmer winters, earlier springs, or summer drought are all concerns (Huntington et al. 2009). As the impacts from the changes could be either negative or positive on tree growth, we consider here if our future forests could balance these effects and remain on the landscapes. Forest productivity and biomass are often used to measure forest resilience, which gives little consideration to changes in forest species diversity and how that effects forest stability (note: stability and resilience are different concepts, see Griffin et al. 2009). Usually, an assessment of climate change impacts on forest species change is based on modeling, rooted on the approach of using climate envelopes of temperature and precipitation limits to define boundaries of tree species, or forest functional types that are supposed to be stable assemblages of tree species (Iverson et al. 2008; Sitch et al. 2008). At a local scale, such an approach may not be sufficient to reflect real changes in species composition, and to provide land managers detailed information for developing useful strategies for climate change adaptation.

We chose the two most common maple species in New England, sugar maple (Acer saccharum) and red maple (Acer rubrum), to assess their current status, looking for approaches that could detect species responses to changing environments. Sugar maple is one of most important ecological and economic tree species in New England. It has the ability to extract water from deep to surface soils, which can benefit other tree species. Concerns about sugar maple decline with crown dieback, reduced growth rate, increased mortality and failed regeneration across much of its range (Bishop et al. 2015) have triggered many studies searching for causes (Houston 1999; Horsley et al. 2000; Hufkens et al. 2012; Halman et al. 2013; Bishop et al. 2015; Bal et al. 2017). Multiple factors likely contribute, including insect defoliation, summer drought, warmer winters, and anthropogenic acidic inputs in the last decades. These have likely combined to make sugar maple less healthy and vulnerable to root diseases, nonnative earthworms, or suppression by other local tree species that are more tolerable to stressors (Houston 1999; Long et al. 2009; Hufkens et al. 2012; Halman et al. 2013; Bishop et al. 2015; Bal et al. 2017).

In the early 1990's, it was generally believed that all maple species were declining, including sugar maple, silver maple, Norway maple and red maple (Walters 2002). However, more recent work suggests that red maple, instead of declining, is becoming one of most abundant tree species in the Northeast (note: silver maple and Norway maple are much less common species in the region) (Fei and Steiner 2007; Pszwaro 2015). Soil warming experiments at Harvard Forest show red maple in particular having phenomenal increases in growth rate and foliage nitrogen content after 7 years' warming in response to increased soil nitrogen availability (Butler et al. 2012). Climate change impacts are likely to account for the increase of red maple abundance on the New England landscape (Fei and Steiner 2007; Butler et al. 2012; Pszwaro 2015). 
The abundance of sugar maple clearly shows Vermont is the center of sugar maple distribution, remaining more evenly distributed and lower in abundance in other areas (Fig. 6a). The mountain valleys with cold winters and deep soils suit sugar maples very well, yet there are few sugar maple along the coastal plain of Massachusetts and Rhode Island. The abundance of red maple is generally higher in warmer regions across the New England latitudinal gradient (Fig. 6c). A relatively lower abundance in Vermont and mountainous New Hampshire is likely due to competition from sugar maple (Fig. 6c). Red maple has a higher importance value and outperforms sugar maple in most of New England as evidenced by greater numbers of trees, although trees are usually smaller than sugar maple trees. Unlike sugar maple, red maple is a species lacking commercial importance (Pszwaro 2015) and is an opportunist distributed across a much broader range. With the climate trending warmer and wetter in New England (Fig. 7), it appears red maple will benefit more than sugar maple. Previous work shows an inverse "J" population structure of diameter classes in red maple of the Northeastern US (Fei and Steiner 2007), suggesting a continuous increase in abundance in the region. Red maple looks to have the potential to gradually replace sugar maple if the climate in New England continues current trends. Such a species change will likely affect other species and biodiversity and cause some instability of ecosystem functioning in some New England forests, given the ecological role sugar maple plays in forests. However, this may not affect forest resilience from the perspective of productivity and biomass because it is obvious that red maple is productive and accumulates biomass effectively. But with generally smaller trees and less well-shaped tree stems, red maple is likely to alter forest structural attributes.

For detecting impacts of a changing environment on species ranges, changes in distribution boundaries of species are usually examined (Iverson et al. 2008). However, there may not be similar replacement species

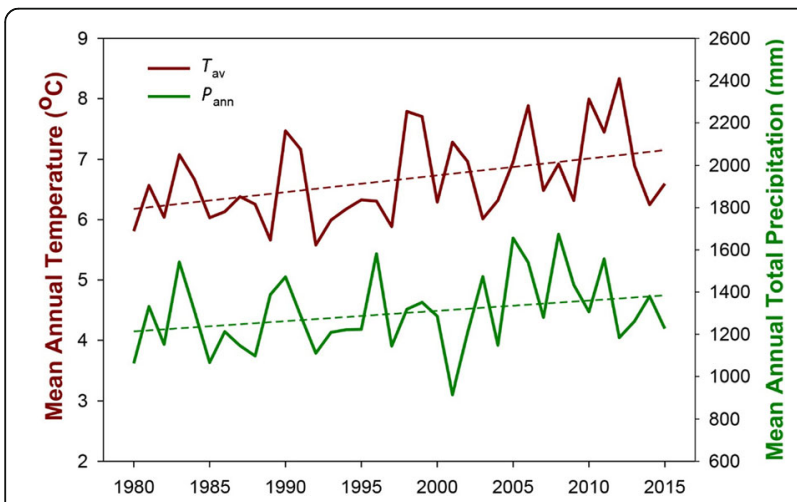

Fig. 7 Climate and trends of last decades in New England states available under future conditions, which are equally suitable for the task both practically and ecologically. With a narrower distribution center and important ecological and economic values, sugar maple could be used to check whether or not the distribution center of a species has shifted over decades by using historical inventory data. This may provide better information than species with less clearly defined ranges. A species such as red maple may not be very useful for distinguishing distribution changes, given its likely greater adaptation ability and wider distribution ranges. Nevertheless, the resilience of a forest to changing climate should not be only measured by its productivity and biomass, likely species responses and stability of key species in the community should also be considered as indicators of forest response.

\section{Conclusion}

Our results, though local and regional, show interesting patterns of forest biodiversity and were consistent with other regional and global studies. These results also reveal new insights and have important implications for the region. We learned that tree species diversity increases from the north to the south at a rate about 2-3 species per latitudinal degree. The species diversity is affected by the sampling areas and linearly related to the number of species occurring in the latitudinal band. Forest tree species diversity and evenness (indicated by SID) are usually higher in the center of a forest type. In transition zones from one forest type shifting to another, the diversity index (SID) is lower but with higher regional differentiation $(\beta)$, which suggests more changes in tree species and less species evenness.

Species diversity is more closely related to tree height than to forest age or living biomass. This may indicate that forest structure (height) and resource (biomass, which is better related to tree age and height than to species diversity) are more likely the foundation to support biodiversity rather biodiversity being a cause to determine forest productivity and biomass as some studies suggested. Forest age also plays an important role for defining forest features; not only do forest biomass and tree height increase with forest age, but species diversity and evenness increase as well.

To foresee the impact of changing climate on forest stability and resilience, the current status and potential changes of single tree species may provide insightful information. In New England, sugar maple is abundant narrowly in Vermont and northern New Hampshire, where mountainous colder winters and drier weather appear to favor the species. Sugar maple does not seem to tolerate coastal sandy soils, and vanishes in Rhode Island and Cape Cod, Massachusetts. Red maple outperforms sugar maple both in abundance and importance value in most New England areas except Vermont and northern 
New Hampshire. There is no clear distribution center for red maple, which increases abundance and importance value along the latitudinal gradient from north to south and also does very well along the wetter coasts. As New England has been getting warmer and wetter over the last few decades, red maple has been more likely benefited by the change in climate and may potentially replace sugar maple. The change could trigger other changes in biodiversity and affect stability of ecosystem functioning in New England forests although it may not affect forest resilience in terms of forest productivity and biomass. However, for evaluating forest responses to a changing climate, we suggest a key species like sugar maple with a narrow distribution range and clear distribution center may serve (via shift of its distribution center) as a better change indicator than a more widely distributed species.

\section{Acknowledgements}

The senior author thanks to Elizabeth Burrill of the USDA Forest Service Northern Research Station for her insightful information concerning the FIA dataset.

\section{Funding}

The authors carry out research under the project NRS-6 "Climate, Fire, and Carbon Cycle Sciences", supported by the USDA Forest Service. This paper is the consequence of a conference presentation. The senior author is grateful to Beijing Forestry University for covering the trip to the conference and generous conference venue facilitating this study.

\section{Authors' contributions}

YP designed the study, performed data analyses and wrote the manuscript; KM processed the data from the FIA database, made maps and provided other technical supports; DYH provided comments and edited the manuscript. All authors read and approved the final manuscript.

\section{Authors' information}

Yude Pan is a senior research scientist of the USDA Forest Service Northern Research Station. She is also a senior investigator at Harvard Forest of Harvard University, Subject Matter Editor for Ecological Applications, Ecosphere, and Associate Editor for JGR-Biogeosciences; Kevin McCullough is a geographer and GIS specialist in the same research unit; David Y. Hollinger is a senior scientist and the Project Leader for the unit of Climate, Fire, and Carbon Cycle Sciences of the USDA Forest Service Northern Research Station.

\section{Competing interests}

The authors declare that they have no competing interests.

\section{Author details}

${ }^{1}$ USDA Forest Service, Durham, NH, USA. ${ }^{2}$ USDA Forest Service, Madison, WI, USA.

Received: 27 November 2017 Accepted: 26 January 2018

Published online: 07 March 2018

\section{References}

Anonymous (2017) Forest inventory and analysis national core field guide. Volume 1: Field data collection procedure for Phase 2 plots, version 7.2. FIA library, USDA Forest Service. https://www.fia.fs.fed.us/library/field-guidesmethods-proc/. Accessed 20 Oct 2017

Bal TL, Storer AJ, Jurgensen MF (2017) Evidence of damage from exotic invasive earthworm activity was highly correlated to sugar maple dieback in the Upper Great Lakes region. Biol Invasions. https://doi.org/10.1007/ s10530-017-1523-0

Bishop DA, Beier CM, Perderson N, Lawrence GB, Stella JC, Sullivan TJ (2015) Regional growth decline of sugar maple (Acer saccharum) and its potential causes. Ecosphere 6(10):179
Brose U, Hillebrand H (2016) Biodiversity and ecosystem functioning in dynamic landscapes. Philos Trans R Soc Lond Ser B Biol Sci 371:20150267. https://doi. org/10.1098/rstb.2015.0267

Butler SM, Melillo JM, Johnson JE, Mohan J, Steudler PA, Lux H, Burrows E, Smith RM, Vario CL, Scott L, Hill TD, Aponte N, Bowles F (2012) Soil warming alters nitrogen cycling in a New England forest: implications for ecosystem function and structure. Oecologia 168:819-828

Cardinale BJ, Wright JP, Cadotte MW, Carroll IT, Hector A, Srivastava DS, Loreau M, Weis JJ (2007) Impacts of plant diversity on biomass production increase through time because of species complementarity. PNAS 104(46):18123-18128

Clark JS, McLachlan JS (2003) Stability of forest biodiversity. Nature 423(5):635-638

Colwell RK, Lees GC (2000) The mid-domain effect: geometric constraints on the geography of species richness. Trees 15:70-76

Díaz S, Wardle DA, Hector A (2009) Incorporating biodiversity in climate change mitigation initiatives. Chapter 11. In: Naeem S, Bunker DE, Hector A, Loreau $M$, Perrings $C$ (eds) Biodiversity, ecosystem functioning, and human wellbeing: an ecological and economic perspective. Oxford scholarship online. https://doi.org/10.1093/acprof:oso/9780199547951.001.0001

Fei S, Steiner KC (2007) Evidence for increasing red maple abundance in the eastern United States. For Sci 53(4):473-477

Franklin JF, Spies TA, Van Pelt R, Carey AB, Thornburgh DA, Berg DR, Lindenmayer DB, Harmon ME, Keeton WS, Shaw DC, Bible K, Chen J (2002) Disturbances and structural development of natural forest ecosystems with silvicultural implications, using Douglas fir forests as an example. For Ecol Manag 155:399-423

Gaston KJ (2000) Global patterns in biodiversity. Nature 405:220-227

Gotelli NJ, Colwell RK (2001) Quantifying biodiversity: procedures and pitfalls in the measurement and comparison of species richness. Ecol Lett 4:379-391

Griffin JN, O'Gorman EJ, Emmerson MC, Jenkins SR, Klein A-M, Loreau M, Symstad A (2009) Biodiversity and the stability of ecosystem functioning. Chapter 6. In: Naeem S, Bunker DE, Hector A, Loreau M, Perrings C (eds) Biodiversity, ecosystem functioning, and human wellbeing: an ecological and economic perspective. Oxford scholarship online. https://doi.org/10.1093/acprof:oso/ 9780199547951.001.0001

Halman JM, Schaberg PG, Hawley GJ, Pardo LH, Fahey TJ (2013) Calcium and aluminum impacts on sugar maple physiology in a northern hardwood forest. Tree Physiol 33(11):1242-1251

He F, Legendre P (2002) Species diversity patterns derived from species-area models. Ecology 83(5):1185-1198

Horsley SB, Long RP, Bailey SW, Hallett RA, Hall TJ (2000) Factors associated with the decline disease of sugar maple on the Allegheny Plateau. Can J For Res 30:1365-1378

Houston DR (1999) History of sugar maple decline. In: Horsley SB, Long RP (eds) Sugar maple ecology and health: proceedings of an international symposium. U.S. Department of Agriculture, Forest Service, Northeastern Research Station. Gen tech rep NE-261, pp 19-26

Hufkens K, Friedl MA, Keenan TF, Sonnentag O, Bailey A, O'Keefe J, Richardson AD (2012) Ecological impacts of a widespread frost event following early spring leaf-out. Glob Change Biol 18(7):2365-2377

Huntington TG, Richardson AD, McGuire KJ, Hayhoe K (2009) Climate and hydrological changes in the northeastern United States: recent trends and implications for forested and aquatic ecosystems. Can J For Res 39(2):199-212

Iverson LR, Prasad AM, Matthews SN, Peters M (2008) Estimating potential habitat for 134 eastern US tree species under six climate scenarios. For Ecol Manag 254:390-406

Kerkhoff AJ, Moriarty PE, Weiser MD (2014) The latitudinal species richness gradient in new world woody angiosperms is consistent with the tropical conservatism hypothesis. PNAS 111(22):8125-8130

Liang J, Crowther TW, Picard N, Wiser S, Zhou M, Alberti G, Schulze ED, McGuire $A D$, Bozzato F, Pretzsch $H$, de Miguel S, Paquette A, Herault B, SchererLorenzen M, Barrett CB, Glick HB, Hengeveld GM, Nabuurs GJ, Pfautsch S, Viana H, Vibrans AC, Ammer C, Schall P, Verbyla D, Tchebakova N, Fischer M, Watson JV, HYH C, Lei XD, Schelhaas MJ, Lu HC, Gianelle D, Parfenova El, Salas C, Lee E, Lee B, Kim HS, Bruelheide H, Coomes DA, Piotto D, Sunderland T, Schmid B, Gourlet-Fleury S, Sonke B, Tavani R, Zhu J, Brandl S, Vayreda J, Kitahara F, Searle EB, Neldner VJ, Ngugi MR, Baraloto C, Frizzera L, Balazy R, Oleksyn J, Zawila-Niedzwiecki T, Bouriaud O, Bussotti F, Finer L, Jaroszewicz B, Jucker T, Valladares F, Jagodzinski AM, Peri PL, Gonmadje C, Marthy W, O'Brien T, Martin EH, Marshall AR, Rovero F, Bitariho R, Niklaus PA, Alvarez-Loayza P, Chamuya N, Valencia R, Mortier F, Wortel V, Engone-Obiang 
NL, Ferreira LV, Odeke DE, Vasquez RM, Lewis SL, Reich PB (2016) Positive biodiversity-productivity relationship predominant in global forests. Science 354:aaf8957-1-aaf8957-12. https://doi.org/10.1126/science.aaf8957

Long RP, Horsley SB, Hallett RA, Bailey SW (2009) Sugar maple growth in relation to nutrition and stress in the northeastern United States. Ecol Appl 19(6):1454-1466

Loreau M, Naeem S, Inchausti P, Bengtsson J, Grime JP, Hector A, Hooper DU, Huston MA, Raffaelli D, Schmid B, Tilman D, Wardle DA (2001) Biodiversity and ecosystem functioning: current knowledge and future challenges. Science 294:804-808

Lyons SK, Willig MR (2002) Species richness, latitude, and scale-sensitivity. Ecology 83(1):47-58

Naeem S, Bunker DE, Hector A, Loreau M, Perrings C (2009) Biodiversity, ecosystem functioning, and human wellbeing: an ecological and economic perspective. Oxford scholarship online. https://doi.org/10.1093/acprof:oso/ 9780199547951.001.0001

Pan Y, Birdsey R, Philipps O, Jackson R (2013) The structure, distribution and biomass of the world's forests. Ann Rev Ecol Evol Syst 44:593-662

Pszwaro $J$ (2015) Growth and stand dynamics of red maple-dominated forests in the Upper Great Lakes Region, USA. Retrieved from the University of Minnesota Digital Conservancy. http://hdl.handle.net/11299/170823. Accessed 20 Sept 2017

Rahbek C (2005) The role of spatial scale and the perception of large-scale species-richness patterns. Ecol Lett 8:224-239

Ricklefs RE, He F (2016) Region effects influence local tree species diversity. PNAS 113(3):674-679

Siccama TG (1974) Vegetation, soil, and climate on the Green Mountains of Vermont. Ecol Monogr 44(3):325-349

Sitch S, Huntingford C, Gedney N, Levy PE, Lomas M, Piao SL, Phillips OL, Castilho CV, Magnusson WE, Molino JF, Monteagudo A, Vargas PN, Montero JC, Feldpausch TR, Coronado ENH, Killeen TJ, Mostacedo B, Vasquez R, Assis RL, Terborgh J, Wittmann F, Andrade A, Laurance WF, Laurance SGW, Marimon BS, Marimon BH, Vieira ICG, Amaral IL, Brienen R, Castellanos H, Lopez DC, Duivenvoorden JF, Mogollon HF, Matos FDD, Davila N, Garcia-Villacorta R, Diaz PRS, Costa F, Emilio T, Levis C, Schietti J, Souza P, Alonso A, Dallmeier F, Montoya AJD, Piedade MTF, Araujo-Murakami A, Arroyo L, Gribel R, Fine PVA, Peres CA, Toledo M, Gerardo AAC, Baker TR, Ceron C, Engel J, Henkel TW, Maas P, Petronelli P, Stropp J, Zartman CE, Daly D, Neill D, Silveira M, Paredes MR, Chave J, Lima DD, Jorgensen PM, Fuentes A, Schongart J, Valverde FC, Di Fiore A, Jimenez EM, Mora MCP, Phillips JF, Rivas G, van Andel TR, von Hildebrand P, Hoffman B, Zent EL, Malhi Y, Prieto A, Rudas A, Ruschell AR, Silva N, Vos V, Zent S, Oliveira AA, Schutz AC, Gonzales T, Nascimento MT, Ramirez-Angulo H, Sierra R, Tirado M, Medina MNU, van der Heijden G, Vela CIA, Torre EV, Vriesendorp C, Wang O, Young KR, Baider C, Balslev H, Ferreira C, Mesones I, Torres-Lezama A, Giraldo LEU, Zagt R, Alexiades MN, Hernandez L, Huamantupa-Chuquimaco I, Milliken W, Cuenca WP, Pauletto D, Sandoval EV, Gamarra LV, Dexter KG, Feeley K, Lopez-Gonzalez G, Silman MR (2008) Evaluation of the terrestrial carbon cycle, future plant geography and climate-carbon cycle feedbacks using five dynamic global vegetation models (DGVMs). Glob Change Biol 14:2015-2039

Steege H-t, Pitman NCA, Sabatier D, Baraloto C, Salomão RP, Guevara JE, Phillips OL, Castilho CV, Magnusson WE, Molino JF, Monteagudo A, Vargas PN, Montero JC, Feldpausch TR, Coronado ENH, Killeen TJ, Mostacedo B, Vasquez R, Assis RL, Terborgh J, Wittmann F, Andrade A, Laurance WF, Laurance SGW, Marimon BS, Marimon BH, Vieira ICG, Amaral IL, Brienen $\mathrm{R}$, Castellanos $\mathrm{H}$, Lopez DC, Duivenvoorden JF, Mogollon HF, Matos FDD, Davila N, GarciaVillacorta R, Diaz PRS, Costa F, Emilio T, Levis C, Schietti J, Souza P, Alonso A, Dallmeier F, Montoya AJD, Piedade MTF, Araujo-Murakami A, Arroyo L, Gribel R, Fine PVA, Peres CA, Toledo M, Gerardo AAC, Baker TR, Ceron C, Engel J, Henkel TW, Maas P, Petronelli P, Stropp J, Zartman CE, Daly D, Neill D, Silveira M, Paredes MR, Chave J, Lima DD, Jorgensen PM, Fuentes A, Schongart J, Valverde FC, Di Fiore A, Jimenez EM, Mora MCP, Phillips JF, Rivas G, van Andel TR, von Hildebrand P, Hoffman B, Zent EL, Malhi Y, Prieto A, Rudas A, Ruschell AR, Silva N, Vos V, Zent S, Oliveira AA, Schutz AC, Gonzales T, Nascimento MT, Ramirez-Angulo H, Sierra R, Tirado M, Medina MNU, van der Heijden G, Vela CIA, Torre EV, Vriesendorp C, Wang O, Young KR, Baider C, Balslev H, Ferreira C, Mesones I, Torres-Lezama A, Giraldo LEU, Zagt R, Alexiades MN, Hernandez L, Huamantupa-Chuquimaco I, Milliken W, Cuenca WP, Pauletto D, Sandoval EV, Gamarra LV, Dexter KG, Feeley K, LopezGonzalez G, Silman MR (2013) Hyperdominance in the Amazonian tree flora. Science 342:1243092. https://doi.org/10.1126/science.1243092
Sullivan MJP, Talbot J, Lewis SL, Phillips OL, Qie L, Begne SK, Chave J, CuniSanchez A, Hubau W, Lopez-Gonzalez G, Miles L, Monteagudo-Mendoza A, Sonke B, Sunderland T, Ter Steege H, White LJT, Affum-Baffoe K, Aiba S, de Almeida EC, de Oliveira EA, Alvarez-Loayza P, Davila EA, Andrade A, Aragao LEOC, Ashton P, Aymard GA, Baker TR, Balinga M, Banin LF, Baraloto C, Bastin JF, Berry N, Bogaert J, Bonal D, Bongers F, Brienen R, Camargo JLC, Ceron C, Moscoso VC, Chezeaux E, Clark CJ, Pacheco AC, Comiskey JA, Valverde FC, Coronado ENH, Dargie G, Davies SJ, De Canniere C, Djuikouo MN, Doucet JL, Erwin TL, Espejo JS, Ewango CEN, Fauset S, Feldpausch TR, Herrera R, Gilpin M, Gloor E, Hall JS, Harris DJ, Hart TB, Kartawinata K, Kho LK, Kitayama K, Laurance SGW, Laurance WF, Leal ME, Lovejoy T, Lovett JC, Lukasu FM, Makana JR, Malhi Y, Maracahipes L, Marimon BS, Marimon B, Marshall AR, Morandi PS, Mukendi JT, Mukinzi J, Nilus R, Vargas PN, Camacho NCP, Pardo G, Pena-Claros M, Petronelli P, Pickavance GC, Poulsen AD, Poulsen JR, Primack RB, Priyadi H, Quesada CA, Reitsma J, Rejou-Mechain M, Restrepo Z, Rutishauser E, Abu Salim K, Salomao RP, Samsoedin I, Sheil D, Sierra R, Silveira M, Slik JWF, Steel L, Taedoumg H, Tan S, Terborgh JW, Thomas SC, Toledo M, Umunay PM, Gamarra LV, Vieira ICG, Vos VA, Wang O, Willcock S, Zemagho L (2017) Diversity and carbon storage across the tropical forest biome. Sci Rep 7:39102. https://doi.org/10.1038/srep39102

Waide RB, Willig MR, Steiner CF, Mittelbach G, Gough L, Dodson SI, Juday GP, Parmenter R (1999) The relationship between productivity and species richness. Annu Rev Ecol Syst 30:257-300

Walters JW (2002) Recognizing and preventing maple decline. Northern Hardwood Notes, North Central Forest Experiment Station, United States Forest Service Whittaker RH (1970) Communities and ecosystems. Macmillan, New York, p 162

\section{Submit your manuscript to a SpringerOpen ${ }^{\mathcal{O}}$ journal and benefit from:}

- Convenient online submission

- Rigorous peer review

- Open access: articles freely available online

- High visibility within the field

- Retaining the copyright to your article

Submit your next manuscript at $>$ springeropen.com 